\title{
PENGEMBANGAN BUDAYA KERJA CHAMPION DALAM PELAKSANAAN TUGAS POKOK DAN FUNGSI DOSEN SERTA PEGAWAI DI FAKULTAS ILMU PENDIDIKAN UNIVERSITAS NEGERI GORONTALO
}

\author{
Arwildayanto \\ Jurusan Manajemen Pendidikan Fakultas Ilmu Pendidikan UNG \\ Email: arwildayanto@ung.ac.id.
}

\begin{abstract}
This study aims to determine, 1) understanding of faculty and staff in terms of the values of work culture Champion, 2) obstacles in the implementation of the cultural values of working champion faculty and staff in the implementation of Auth, 3) identify the role of leadership in the development of work culture champion lecturer and employees, 4). Auth achievement for faculty and employees, 5) the influence of work culture champion faculty and employees to the achievement of the implementation of the Auth. This study uses a qualitative method. Data were collected by interview, observation and documentation in order to dig deeper into the work culture champion lecturers and administrative staff FIP UNG. The object of this study are professors and employees a total of 93 people. This study found the first, a fact that reinforces the results of previous studies, employee perceptions about the implementation of the Auth is the good category is subjective because it is understood from finished or not duties, not pay attention to the level of satisfaction and quality of service on the stakeholders (stakeholders), both identities UNG, vision, mission FIP give effect to the development of work culture lecturers and employees, the three values of work culture and employee dominant lecturers comprising; a) cooperation, b) innovation, c) religion, d) achievement orientation, e) empathy, f). honesty, g) mutual cooperation, h) moral, i) optimistic, j) relationships, the four working philosophy faculty and employees are constructed of acculturation and philosophy of work of cultural entities origin dominant namely culture Gorontalo with the philosophy of custom bersendikan syarak-syarak bersendikan Al -qur'an, and culture of gotong royong (huyula), Bugis and Makassar entity with Siri philosophy of 'Na Passe ot Pacce, as well as Java and surrounding entities have relented wani sublime philosophy wahasane, working into the fifth appearance of behavior, namely; gotong royong (huyula), single-minded use of personal items, zakat books, the use of technology in the lecture and administrative affairs and a commitment not to smoke on campus FIP UNG, There are still some appearance of work that still needs to touch in the development of work culture lecturers and employees in a structured, systematic and massive (TSM).
\end{abstract}

Keywords: Work Culture Champion, Main Duties and Functions

\begin{abstract}
Abstrak: Penelitian ini bertujuan mengetahui, 1) pemahaman dosen dan pegawai mengenai nilai-nilai budaya kerja Champion, 2) hambatan dalam implementasi nilai-nilai budaya kerja champion dosen dan pegawai dalam pelaksanaan Tupoksi, 3) mengidentifikasi peran pimpinan dalam pengembangan budaya kerja champion dosen dan pegawai, 4). Ketercapaian Tupoksi dosen dan pegawai, 5) pengaruh budaya kerja champion dosen dan pegawai terhadap ketercapaian pelaksanaan Tupoksi. Penelitian ini menggunakan metode kualitatif. Pengumpulan data dilakukan dengan wawancara, observasi, dan dokumentasi guna menggali lebih dalam tentang Budaya kerja champion
\end{abstract}


dosen dan pegawai administrasi FIP UNG. Objek penelitian ini adalah dosen dan pegawai sebanyak 93 orang. Penelitian ini menemukan pertama, fakta yang memperkuat hasil penelitian sebelumnya, persepsi pegawai tentang pelaksanaan Tupoksi berada pada kategori baik bersifat subjektif karena dipahami dari selesai atau tidaknya tupoksi, belum memperhatikan tingkat kepuasaan dan kualitas layanan pada pemangku kepentingan (stakeholders), kedua jati diri UNG, visi, misi FIP memberikan pengaruh bagi pengembangan budaya kerja dosen dan pegawai, ketiga nilai-nilai budaya kerja dosen dan pegawai yang dominan terdiri; a) kerjasama, b) inovasi, c) agama, d) orientasi berprestasi, e) empati, f). kejujuran, g) gotong royong, $h$ ) moral, i) optimis, j) hubungan, keempat filosofi kerja dosen dan pegawai terkonstruksi dari akulturasi budaya dan filosofi kerja dari entitas budaya asal yang dominan yakni budaya Gorontalo dengan filosofi adat bersendikan syarak-syarak bersendikan Al-qur'an, dan budaya gotong royong (huyula), entitas Bugis dan Makassar dengan filosofi Siri' Na Passe ot Pacce, serta entitas Jawa dan sekitarnya memiliki filosofi wani ngalah luhur wahasane, kelima penampilan kerja yang menjadi perilaku, yakni; gotong royong (huyula), ikhlas menggunakan barang pribadi, zakat buku, penggunaan teknologi dalam perkuliahan dan urusan administrasi dan komitmen tidak merokok di lingkungan kampus FIP UNG, Masih ada beberapa penampilan kerja yang masih perlu sentuhan dalam pengembangan budaya kerja dosen dan pegawai secara terstruktur, sistematis dan massif (TSM).

Kata Kunci : Budaya Kerja Champion, Tugas Pokok dan Fungsi

\section{PENDAHULUAN}

Kajian tentang budaya kerja pegawai UNG dan pengaruhnya terhadap pelaksanaan tugas pokok dan fungsi (Tupoksi) yang peneliti lakukan tahun 2013, memberikan rekomendasi penting dilakukan penelitian lanjutan, terkait dengan sinkronisasi pemahaman pegawai tentang pelaksanaan Tupoksi yang dikerjakannya dengan budaya kerja yang ditampilkannya. Fakta yang ditemui menunjukkan persepsi pegawai tentang pelaksanaan Tupoksi berada pada kategori baik, sedangkan budaya kerja yang ditampilkan hanya berada pada kategori cukup memberikan kesimpulan bahwa budaya kerja tidak berpengaruh terhadap ketercapaian pelaksanaan Tupoksi pegawai. Setelah dilakukan penelusuran ditemukan bahwa pemahaman pegawai terhadap ketercapaian pelaksanaan Tupoksi ternyata disebabkan adanya pandangan dari peningkatan jumlah mahasiswa yang dilayaninya tiap tahun menunjukkan trend (kecendrungan) positif. Peningkatan jumlah mahasiswa UNG dipandang pelaksanaan Tupoksinya sudah berjalan dengan baik. Padahal persepsi pegawai ini bagaikan sebuah fatamorgana. Karena pilihan memasuki perguruan tinggi negeri (PTN) di luar UNG sangat terbatas. UNG menjadi satu-satunya pilihan yang realistis dari masyarakat Gorontalo dan sekitarnya memasukkan anaknya ke Universitas Negeri. Disamping itu peningkatan jumlah mahasiswa UNG disebabkan angka partisipasi kasar (APK) masyarakat untuk menempuh jenjang pendidikan tinggi di Provinsi Gorontalo mengalami peningkatan yang signifikan. Dengan demikian, ketercapaian pelaksanaan Tupoksinya belum terkait kualitas layanan yang dilakukannya, sehingga budaya kerja yang mereka miliki dan tampilkan belum berada pada kategori baik.

Fakta-fakta di atas mendorong peneliti untuk mengetahui dan mendalami budaya kerja dosen dan pegawai dalam konteks yang lebih luas kaitannya dengan pelaksanaan Tupoksinya. Belum meningkatnya penerapan budaya kerja dosen dan pegawai tentu 
disebabkan oleh regulasi yang mengatur pembentukan, pembinaan dan pengembangan budaya dosen dan pegawai di FIP UNG belum diorganisir secara terstruktur sistematis dan massif.

Untuk memperkuat dan mempercepat (akselarasi) gerakan budaya kerja sebagai kekuatan kolektif, penelitian ini berusaha menggali dan mendapatkan informasi yang utuh tentang budaya kerja dosen dan pegawai di FIP UNG sebagai pilar pelaksana operasional dalam peningkatan mutu Sumber Daya Manusia (SDM) dan mutu lulusan UNG ke depannya. Kajian ini juga mencermati “political will” Senat FIP UNG, Rabu tanggal 25 Februari 2015 Nomor 568/UN47.B1/DT/2015 menyetujui dokumen Budaya Kerja dosen dan pegawai FIP UNG, dengan akronim “Champion”, terdiri dari competitiveness, honour, achievemen orientation, morality, pioneering, innovation, optimism, and nationalism.

Regulasi yang dikeluarkan pimpinan fakultas menjadi acuan berpikir, berperilaku, bertindak dan bekerja dosen dan pegawai melaksanakan Tupoksinya. Namun masih ada kecendrungan para dosen dan staf mengabaikan kinerja untuk keberhasilan memperoleh akreditasi atau employer branding, yang merupakan pilar utama untuk meningkatkan mutu lulusan. Untuk memenuhi harapan itu, Arianto (2014; 191-200) memandang budaya kerja menjadi faktor yang memiliki pengaruh positif (signifikan) terhadap peningkatan kinerja. Budaya kerja tentunya tidak lepas dari konteks budaya yang dimaksud secara universal terjadi di ruang kerja, ditempat kerja atau organisasi kerja. William G. Tierney $(1988 ; 2)$ menjelaskan researchers and practitioners alike often view cultur as a new management approach that will not only cure a variety of organizational ills but will serve to explain virtually every event that occurs within an organizational.

Kajian budaya kerja dosen dan pegawai ini penting dilakukan agar tugas pokok dan fungsi kerjanya bisa dicapai dengan baik sekaligus mampu meningkatkan kinerjanya Bertolak dari pemikiran ini dipandang perlu dilakukan kajian mendalam tentang budaya kerja Champion dosen dan pegawai dengan harapan tugas pokok dan fungsi yang melekat dari pekerjaannya bisa terlaksana dan tercapai dengan baik, serta bisa memuaskan harapan stakeholders dari unit kerjan yang dilayaninya.

Fokus Penelitian, terdiri dari 1) nilai-nilai Budaya kerja Champion dosen dan pegawai FIP UNG, 2) hambatan implemenyasi budaya kerja Champion dosen dan pegawai FIP UNG, 3) peran pimpinan Fakultas dalam penerapan budaya kerja champion dosen dan pegawai FIP UNG, 4) ketercapaian Tupoksi dosen dan pegawai FIP UNG, 5) pengaruh budaya kerja Champion terhadap ketercapaian pelaksanaan Tupoksi dosen pegawai FIP UNG.

Tujuan dan Manfaat Penelitian, untuk mendeskripsikan, antara lain : 1) nilai-nilai Budaya kerja Champion FIP UNG, 2) hambatan yang dihadapi dalam implemenyasi budaya kerja champion FIP UNG, 3) Peran pimpinan Fakultas dalam penerapan budaya kerja champion FIP UNG, 4) ketercapaian Tupoksi dosen dan pegawai FIP UNG, 5) pengaruh budaya kerja Champion terhadap ketercapaian pelaksanaan Tupoksi dosen dan pegawai FIP UNG.

\section{KAJIAN TEORI}

Budaya Kerja Champion. Makna budaya terus berkembang sebagai cara manusia mengaktualisasikan nilai (value), karsa (creativity) dan hasil karyanya (performance) sebagai keseluruhan usaha rohani dan materi termasuk potensi-potensi maupun keterampilan masyarakat atau kelompok manusia dalam organisasi (Arwildayanto, 2011; 
16-18). Budaya tumbuh dan berkembang dalam sebuah organisasi saling berinteraksi satu sama lain. Termasuk organisasi fakultas di sebuah perguruan tinggi memiliki budaya organisasi yang membedakannya dengan fakultas lainnya. Tri Widodo (2012; 19) menjelaskan budaya organisasi merupakan kumpulan kepercayaan, harapan, dan nilai-nilai yang dianut bersama oleh anggota organisasi dan diwariskan dari satu generasi ke generasi berikutnya. Budaya organisasi memiliki peran untuk mengubah sikap dan juga perilaku sumber daya manusia atau pegawai yang ada agar dapat meningkatkan produktivitas kerja untuk melaksanakan tugas pokok dan fungsinya dalam memberikan layanan serta dalam menghadapi berbagai tantangan organisasi di masa yang akan datang. Hal senada disampaikan Lila Tintami dkk (2012; 3) menjelaskan budaya organisasi menjadi filosofi dasar organisasi yang memuat keyakinan, norma-norma, dan nilai-nilai bersama yang menjadi karakteristik inti tentang bagaimana melakukan sesuatu dalam organisasi diantara di tempat seseorang bekerja atau mencari nafkah. Kementerian Pendidikan Nasional $(2010 ; 6)$ mendefenisikan budaya organisasi di dalamnya termasuk budaya kerja merupakan sistem nilai organisasi yang dianut oleh anggota organisasi, kemudian mempengaruhi cara kerja, sikap dan berperilaku anggota organisasi lainnya. Hal yang sama juga dijelaskan oleh Sun, S. (2008;140-141). Bahwa every organization has its own unique culture or value set, and different organization may have its own comprehension of culture meaning. The culture of the organization is typically created unconsciously, based on the values of the top management or the founders of an organization. In order to achieve a successful culture, managers shouldn't ignore organizational culture and its themes, because culture can be used as a competitive advantage during organizational development, and a strong culture (one in which beliefs and values are widely shared and strongly held) can also offer many ad vantages, such as cooperation, control, communication or commitment. Meanwhile, the importance of organizational culture is growing as the result of several recent developmets, and the cultural themes can be used constantly to measure the culture of the organization.

Disamping itu budaya kerja sebenarnya sudah lama dikenal manusia, namun belum disadari suatu keberhasilan kerja berakar pada nilai-nilai yang dimiliki dan perilaku yang menjadi kebiasaan orang dalam organisasi bekerja. Hal senada disampaikan Siregar, A.N dan Saridewi, T.R (2010;32) menjelaskan budaya kerja itu merupakan falsafah yang didasari pandangan hidup sebagai nilai-nilai yang menjadi sifat, kebiasaan dan juga pendorong yang dibudayakan dalam suatu kelompok dan tercermin dalam sikap menjadi perilaku, cita-cita, pendapat, pandangan serta tindakan yang terwujud sebagai kerja. Dalam perspektif lebih moderat, Rachmawati, E., Warella, Y., \& Hidayat, Z. (2006) budaya kerja terkait dengan peran pemimpin menjadi panutan (role model) yang bertugas menyiapkan generasi berikutnya memimpin dengan nilai-nilai budaya kerja terbaik, mulai sejak organisasi tumbuh serta adaptif dengan perkembangan masa kini. Lembaga Administrasi Negara (2004:12) memaknai budaya kerja dalam konteks yang lebih luas; pertama, budaya kerja aparatur negara diartikan sebagai sikap, perilaku individu dan kelompok aparatur negara yang didasari atas nilai yang diyakini kebenaran dan telah menjadi sifat serta kebiasaan dalam melaksanakan tugas dan pekerjaan sehari-hari, kedua, budaya kerja merupakan pola tingkah laku dan nilai-nilai yang disepakati karyawan dalam bekerja, misalnya perilaku dalam menjalankan tugas, karier, promosi, reward dan sebagainya, ketiga, budaya kerja berarti cara pandang atau cara seseorang memberikan makna terhadap "kerja”. 
Uraian di atas, dapat disimpulkan budaya kerja champion itu merupakan formulasi budaya kerja yang berbasis pada semangat untuk menunjukkan nilai-nilai prestasi tinggi dalam bekerja. Sistem nilai yang ditransformasi ini dipercayai, dan disikapi sebagai suatu kebiasaan seseorang atau kelompok yang mempengaruhi perilaku kerja, sikap kerja dan cara kerja aparatur atau pegawai yang ada di suatu organisasi untuk menunjukkan kerja yang dilakukan berorientasi pada nilai-nilai prestasi (champion).

Nilai-nilai Budaya Kerja Champion FIP UNG. Nilai-nilai budaya kerja champion FIP UNG merupakan turunan dari nilai-nilai baru Kementerian Pendidikan Nasional yang berorientasi pada pencapaian sasaran, kualitas hasil kerja (output), serta pencapaian prestasi kerja (Kemdiknas, 2008;36). Nilai-nilai budaya kerja Champion sebagai instrument untuk mewujudkan visi FIP UNG 2025 menjadi pelopor inovasi pendidikan yang kompetitif dan bermartabat berbasis budaya lokal diperlukan semangat besar untuk menempuh perjalanan panjang yang penuh rintangan dan ketidakpastian, untuk menghindari rintangan-rintangan dalam perjalanannya. Tanpa semangat yang besar, tentu perjalanan jangka panjang akan terhenti dan gagal atau menyimpang dari visi FIP UNG 2025 yang diinginkan.

Pernyataan filosofi di atas yang mengedepankan pentingnya organisasi bergerak berdasar pada prinsip kerja keras, cerdas, dan tuntas yang bertujuan akhir pada dimensi illahi bahwa manusia diwajibkan beribadah merupakan doktrinasi nilai-nilai budaya kerja champion yang disepakati FIP UNG ke depannya.

Nilai-nilai budaya kerja champion menjadi nilai dasar dalam menimbulkan kesadaran akan pekerjaan yang ditekuninya dianggap penting dan seharusnya ada dalam peningkatan produktivitas layanan terbaik FIP UNG. Setelah melalui diskusi panjang dengan para pemangku kepentingan (stakeholders) maka disepekati nilai-nilai dasar budaya kerja champion Fakultas Ilmu Pendidikan UNG.

Tabel 1. Nilai Budaya Kerja Champion FIP UNG

\begin{tabular}{|c|c|}
\hline $\begin{array}{c}8 \text { Nilai } \\
\text { Budaya Kerja Fip Ung } \\
\end{array}$ & $\begin{array}{l}15 \text { Nilai Perilaku Utama } \\
\text { Civitas Akademika Fip Ung }\end{array}$ \\
\hline $\begin{array}{l}\text { Competitiveness = Daya Saing } \\
\text { Peningkatan Produktifitas kerja menggunakan sumber } \\
\text { daya yang ada }\end{array}$ & $\begin{array}{l}\text { - Diri diabdikan (batanga pomaya) } \\
\text { - Tidak mengeluh, pantang menyerah }\end{array}$ \\
\hline $\begin{array}{l}\text { Honour = pelayanan maksimal } \\
\text { Bekerja dengan target tinggi }\end{array}$ & $\begin{array}{l}\text { - Nyawa dikorbankan (nyawa } \\
\text { podungalo) } \\
\text { - Pelayanan prima (excellence service) }\end{array}$ \\
\hline $\begin{array}{l}\text { Achievement Orientation }=\text { Orientasi berprestasi } \\
\text { Bekerja dengan baik dan melampaui standar prestasi } \\
\text { yang ditetapkan dan terus menerus meraih keunggulan }\end{array}$ & - Profesional \\
\hline $\begin{array}{l}\text { Morality = Moralitas } \\
\text { Sifat, karakter dan perilaku pegawai yang bersumber } \\
\text { dari agama yang diyakininya maupun menurut etika } \\
\text { atu norma yang berlaku di masyarakat. }\end{array}$ & $\begin{array}{l}\text { - } \text { Berbudaya } \\
\text { - Religius } \\
\text { - Disiplin, Konsisten dan } \\
\text { Bertanggungjawab }\end{array}$ \\
\hline $\begin{array}{l}\text { Pioneering : Kepeloporan } \\
\text { Semangat, sikap dan kesukarelawanan yang dilandasi }\end{array}$ & $\begin{array}{l}\text { - Harta direlakan (upango potombulu) } \\
\text { - Menaruh perhatian pada customer, }\end{array}$ \\
\hline
\end{tabular}


Lanjutan Tabel 1

kesadaran diri atas tanggung jawab sosial untuk menciptakan sesuatu dan atau mengubah gagasan menjadi sebuah karya nyata yang dilaksanakan secara konsisten, gigih dan diakui oleh masyarakat luas karena mampu memberikan nilai tambah pada sendisendi kehidupan masyarakat.

Innovation: Inovasi

Berpikir untuk meningkatkan cara kita bekerja, membuatnya lebih mudah, lebih baik, dan lebih cepat atau kemampuan untuk selalu menciptakan sesuatu yang baru

Optimism : Optimis

Sikap dalam melaksanakan pekerjaan selalu • Yakin Usaha Sampai menyakini bisa diselesaikan

Nationalism : Nasionalisme mencitakan dan mempertahankan kedaulatan Negara dengan mewujudkan satu konsep identitas bersama Negara Kesatuan Republik Indonesia

rekan kerja, masyarakat,

- Kreatif dan Inovatif

Sumber : Dokumen Pengembangan Budaya Kerja Champion FIP UNG 2015

Tupoksi Dosen dan Pegawai administrasi. Pertama. Tugas pokok dan fungsi Dosen. Memperhatikan amanat yang terkandung dalam Undang-undang Republik Indonesia Nomor 14 Tahun 2005 tentang Guru dan Dosen, dijelaskan bahwa Dosen adalah pendidik profesional dan ilmuwan dengan tugas pokok dan fungsi dosen yang utama adalah mentransformasikan, mengembangkan, dan menyebarluaskan ilmu pengetahuan, teknologi, dan seni melalui pendidikan, penelitian, dan pengabdian kepada masyarakat termasuk tugas penunjang tridharma perguruan tinggi, antara lain 1) melaksanakan proses pendidikan berupa proses pembelajaran, terdiri a) melaksanakan perencanaan pembelajaran b) melaksanakan pembelajaran, c) melaksanakan evaluasi pembelajaran, d) melaksanakan penilaian hasil belajar mahasiswa, e) melaksanakan proses belajar sepanjang hayat untuk memelihara, meningkatkan kualitas keilmuan dan kepribadiannya, f) melaksanakan fungsi manajemen pendidikan. Dalam pembelajaran, dosen memiliki wewenang: a) mengembangkan dan mengimplementasikan suatu metode pembelajaran yang dipertimbangkan efisien dan efektif untuk mencapai tujuan pembelajaran; b) memanfaatkan fasilitas pembelajaran yang menunjang kelancaran proses pembelajaran, c) memiliki kebebasan dalam memberikan penilaian dan dalam menentukan kelulusan peserta didik. 2) Melaksanakan penelitian dan pengembangan karya ilmiah, antara lain; a) melakukan kegiatan (menghasilkan karya) penelitian; b) Menerjemahkan/ menyadur buku ilmiah; c) mengedit/menyunting karya ilmiah; d) membuat rancangan dan karya teknologi; e) membuat rancangan dan karya seni. 3) Melaksanakan pengabdian pada masyarakat, terdiri dari: a) melaksanakan tugas sebagai pimpinan dalam lembaga pemerintahan/pejabat negara sehingga harus dibebaskan dari jabatan organiknya; b) melaksanakan pengembangan hasil pendidikan dan penelitian yang dapat dimanfaatkan oleh masyarakat; c) memberi latihan/penyuluhan/penataran pada masyarakat; d) memberi pelayanan kepada masyarakat atau kegiatan lain yang menunjang pelaksanaan tugas umum pemerintah dan pembangunan; e) membuat/menulis karya 4) Melaksanakan tugas di bidang penunjang tridharma perguruan tinggi, dosen dapat juga; a) menjadi anggota dalam suatu panitia/badan pada perguruan tinggi, b) menjadi anggota panitia/badan pada lembaga 
pemerintah; c) menjadi anggota organisasi profesi; d) mewakili perguruan tinggi/lembaga pemerintah duduk dalam panitia antar lembaga; e) menjadi anggota delegasi nasional ke pertemuan internasional; f) berperan serta aktif dalam pertemuan ilmiah; g) menulis buku pelajaran SLTA kebawah; h) m empunyai prestasi di bidang olahraga/kesenian/sosial.;

Kedua. Tugas Pokok dan Fungsi Pegawai Administrasi. Tugas pokok dan fungsi pegawai di lingkungan perguruan tinggi, khususnya di tingkat fakultas diatur berdasarkan Keputusan Mendiknas RI Nomor 258/D/O/2006 tentang rincian jabatan sebagai berikut di tingkat fakultas, terdiri dari 1) Kabag Tata Usaha, 2) kasubag Pendidikan, dibantu Pengadministrasi Pendidikan, Pengelola Data Bidang Akademik, Pengadministrasi Umum Perpustakaan, 3) Kasubag Keuangan dan Kepegawaian, dibantu Pengadministrasi Kepegawaian, Bendahara Pembantu Pengeluaran, Penyusun dan Anggaran Fakultas, 4) Kasubag Kemahasiswaan, Pengadministrasi Kemahasiswaan, Pengadministrasi Kemahasiswaan dan Alumni, 5) Kasubag Umum dan Perlengkapan, dibantu Agendaris, Caraka, Penata Arsip, Penyusun Laporan dan Pengelola BMN, Pengadministrasi Kerumahtanggaan, Pengadministrasi Operasi Kendaraan Dinas, 6) Sekretaris Pimpinan (Dekan dan Wakil Dekan)

Ketercapaian (Tupoksi) Dosen dan Pegawai. Pemahaman tentang Tupoksi dilihat dari istilah tugas, fungsi, tugas pokok dan fungsi. Tugas itu sendiri mengemban padanan peran, kewajiban, darma, dan pekerjaan yang dilakukan seseorang. Moekijat (1998;11) mendefenisikan tugas sebagai bagian atau suatu unsur atau komponen dari suatu jabatan. Tugas adalah gabungan dari dua unsur (elemen) atau lebih sehingga menjadi suatu kegiatan yang lengkap. (Stone dalam Moekijat, 1998:10) menyatakan "A task is a specific work activity carried out to achieve a specific purpose".Didukung (Dale Yoder dalam Moekijat M 1998:9) mendefenisikan "The Term Task is frequently used to describe one portion or element in a job" defenisi ini memberikan rambu-rambu tugas itu merupakan suatu kewajiban yang harus dikerjakan, tanggung jawab yang dilakukan baik secara rutin maupun berkala atau perintah untuk berbuat atau melakukan sesuatu demi mencapai suatu tujuan. Termasuk di dalamnya pekerjaan menjadi dosen dan pegawai, tentu ada yang menjadi tugas pokok keduanya.

Secara sederhana tugas pokok (duties) staf atau pegawai itu merupakan "engaged in or responsible for assigned work", a task or action that a person is bound to perform for moral or legal reasons, an action or task required by a person's position or occupation (Error! Hyperlink reference not valid..com). Bahkan Henri Frédéric Amiel menyatakan tugas pokok dosen dan pegawai, dimana Our duty is to be useful, not according to our desires but according to our powers (http://thoughts.forbes. com). Dari sisi manajemen Tupoksi dosen dan pegawai ditetapkan untuk suatu jabatan atau pekerjaan sangat berpengaruh secara langsung terhadap efektivitas kerja dosen dan pegawai itu sendiri melalui ketercapaian (reachability) pelaksanaan tugas secara benar dan konsisten berdasarkan deskripsi pekerjaan (job description) dan spesifikasi pekerjaan. Ketercapaian (reachability) kerja dosen dan pegawai tidak jauh berbeda dengan konsep keterkontrolan Tupoksi yang diembannya dalam sistem linear kontinu dari segenap pekerjaan yang menjadi kewajibannya. Indikatornya dilihat prosentase atau fluktuasi keberhasilan tujuan, sasaran, agenda, program kerja, kesesuaian dalam pelaksanaan pekerjaan yang menjadi kewajiban dosen dan pegawai di tempat bekerjanya. Ketercapaian Tupoksi dosen dan pegawai dilihat dalam perspektif successful completion; accomplishment, hal ini ditandai dengan action, performance, track record yang bisa diamati secara normatif maupun 
objektif. Ketercapaian Tupoksi dosen dan pegawai dilihat juga dari mindsetnya untuk menyelesaikan pekerjaannya menggunakan pendekatan "think out box". Hal ini tentu memerlukan kecerdasan dan kebiasaan untuk melakukan terobosan, alternatif dan kreativitas yang tinggi diluar kebiasaan maupun cara-cara biasa yang seringkali dilakukan oleh dosen dan pegawai kebanyakan.

\section{METODE}

Penelitian ini menggunakan metode kualitatif dengan pendekatan etnografi dan fenomenologis dengan alasan; pertama, realitas yang ada dalam konteks budaya kerja pada dasarnya terkonstruksi secara holistik. terfokus, sesuai dengan konteks dimana peristiwa budaya kerja champion itu diteliti, kedua, penelitian ini mengeksplorasi hakekat hubungan antara peneliti dengan subjek yang diteliti secara lebik peka, dan dapat dilakukan penajaman terhadap pola-pola nilai budaya kerja champion yang ada, terkonstruksi dari adat-istiadat di provinsi Gorontalo dapat mempengaruhinya. (Moleong $(1995 ; 5)$.

Objek penelitian ini dosen dan pegawai FIP UNG yang berjumlah 97. Penentuan objek dosen dan pegawai menurut Nasution (1988;32) sebagai sumber yang dapat memberi informasi, baik dalam bentuk peristiwa, manusia, situasi yang diobservasi., Peneliti melakukan wawancara secara "purposive” bertalian dengan tujuan tertentu. Caranya menurut Bogdan dan Biklen (1998;21) informan terpilih diminta untuk menunjuk orang lain, setelah dirinya, dan seterusnya sampai peneliti dapat menerima informasi yang jenuh, sama taraf "redundancy". Proses sering disebut "snowball sampling" berurutan mulai dari Dekan sampai segenap dosen dan pegawai lainnya. Sedangkan sumber data dalam penelitian kualitatif ini collaborators, interviewing, video and photographs, participant observer's, documents.

Prosedur pengumpulan data dilakukan peneliti menseleksi aspek-aspek yang khas, dengan dibantu mahasiswa yang sedang mengambil mata kuliah manajemen sumber daya semester Ganjil 2015/2016. Peneliti membuat pola/tema dengan cara yang lebih halus serta mendalam. Perekaman data dilengkapi dengan kerangka acuan pertanyaan berbentuk pedoman wawancara disusun peneliti sendiri (participant observation). Prosedur penelitian ini, dilakukan melalui 1) teknik observasi berperan serta, 2) teknik wawancara, 3) teknik dokumentasi.

Analisis data penelitian ini menggunakan teknik analisis yang dianjurkan Miles dan Huberman (1992;23) yaitu "interaktif analisis data" dengan komponen, antara lain reduksi data, penyajian data, dan penarikan kesimpulan atau verifikasi. Pengecekan keabsahan data dilakukan mengikuti saran Lincoln dan Guba dalam Faisal (1990;31-32), yaitu 1) keterpercayaan (credibility), 2) keteralihan (tranferability), 3) dapat dipertanggung jawabkan (dependability), 4) kepastian atau objektif (confirmability). Tahap-tahap penelitian ini di bagi ke dalam tiga tahapan sebagaimana dijelaskan Moleong (1998;27), yaitu 1) Tahap Pra Lapangan, 2) Tahap Pengembangan Disain, dan 3) Penelitian Sesungguhnya.

Temuan Penelitian, ada beberapa temuan penelitian tentang pengembangan budaya kerja champion dosen dan pegawai FIP UNG, antara lain:

1. Budaya kerja dosen dan pegawai administrasi FIP UNG bersumber dari visi UNG 2035 menjadi “leading university” sekaligus sejak tahun 2015 memperkokoh jati diri menjadi 
kampus “committed culture and innovation”. Jati diri UNG ini menjadi gerakan budaya untuk "move on" secara kolektif dalam pengembangan kebudayaan dan inovasi berbasis potensi regional di kawasan Asia. Turunan gerakan budaya pada level universitas dilanjutkan dalam gerakan budaya pada tingkatan Fakultas Ilmu Pendidikan yang berkomitmen dalam visi FIP UNG 2025 menjadi pelopor inovasi pendidikan yang kompetitif dan bermartabat berbasis budaya lokal. Sinergitas gerakan budaya dari tingkatan universitas dan fakultas menunjukkan linearitas alur, ritme dan irama satu tekad penanaman nilai-nilai competitiveness pada ruang lingkup global namun tetap fokus merawat dan menjaga keanekaragaman, kekayaan dan keunikan budaya lokal (local wisdom). Inilah wajah dan ronah budaya kerja yang sedang ditanamkan dan disemaikan pada jadi diri dosen dan pegawai administrasi FIP UNG.

2. filosofi kerja menjadi landasan formal dalam mencari identitas, dan jati diri kampus UNG bersumber dari kekayaan budaya lokal, yakni filosofi lima sendi Negeri Gorontalo (Payu Limo to Talo Pei Hulalu) dan Adat Bersendikan Syarak- Syarak Bersendikan Al-Qur'an (Adati Hula-hula'a ta Sara'a-Sara'a Hula-hula'a Kuru'ani). Disamping itu ada filosofi yang terdapat dalam artefak kampus berupa konstruksi rektorat yang bentuk "toga” memiliki makna civitas akademika UNG selalu bekerja dan berpikir rasional dari berbagai perspektif.

3. Ada 10 nilai kerja dominan (kuat) membentuk budaya kerja champion dosen dan pegawai administrasi FIP UNG, antara lain 1) Kerjasama (Team Work), 2) Inovasi (Innovation), 3) Agama (Religious), 4) Orientasi Berprestasi (Achievemen Orientation), 5) Empati (Emphaty), 6). Kejujuran (Fairness), 7) Gotong Royong (huyula) , 8) Moral (Morality), 9) Optimis (Optimism), 10) Hubungan (Relationship).

4. Kendala budaya kerja Champion belum tumbuh dan berkembang secara ideal sesuai harapan, diantaranya hambatan yang terlihat dari beberapa perilaku dosen dan pegawai antara lain, 1) Absensi perkuliahan masih banyak yang di rapel di akhir perkuliahan, 2) dosen masih dihantui pikiran sudah berada pada usia lanjut, 3) pegawai bekerja belum menggunakan waktu secara efektif, 4) kemampuan dosen dan pegawai dalam hal bahasa asing masih rendah dan keinginan mengikuti studi lanjut lebih senang di kota Gorontalo. Fakta perilaku kerja ini menjadi hambatan dalam pengembangan budaya kerja Champion ke depannya.

5. Kepemimpinan dekan dan wakil dekan dalam indoktrinasi nilai-nilai budaya kerja dilakukan melalui berbagai pertemuan (rapat), diantaranya; a) pertemuan pimpinan fakultas dan dosen, rapat forum ilmiah FIP JIP 2015, Yudisiom akhir program dan kegiatan keagamaan

6. Ketercapaian Tupoksi dosen dan pegawai FIP UNG sudah tercapai, karena dipersepsikan dalam konteks selesai atau tidaknya pekerjaan tersebut. Namun secara factual sisi kualitas layanan dalam pelaksanaan Tupoksi masih perlu ditingkatkan, karena masih ditemukan beberapa hambatan dalam pelaksanaan budaya kerja champion dosen dan pegawai FIP.

7. Pelaksanaan tupoksi dosen dan pegawai berdasarkan fakta dan dokumen wawancara menunjukkan ada pengaruh dari budaya kerja Champion. Hal ini didukung dengan penampilan kerja, diantaranya: 1) budaya gotong royong, (huyula), 2) Tidak merokok dilingkungan FIP, 3) zakat buku, 4) penggunaan teknologi dalam perkuliahan dan sistem administrasi. Perilaku-perilaku kerja ini memberikan pengaruh yang signifikan bagi ketercapaian pelaksanaan Tupoksi dosen dan pegawai FIP UNG. 
Champion dosen dan pegawai administrasi FIP UNG sebagai berikut terlihat Gambar 1.

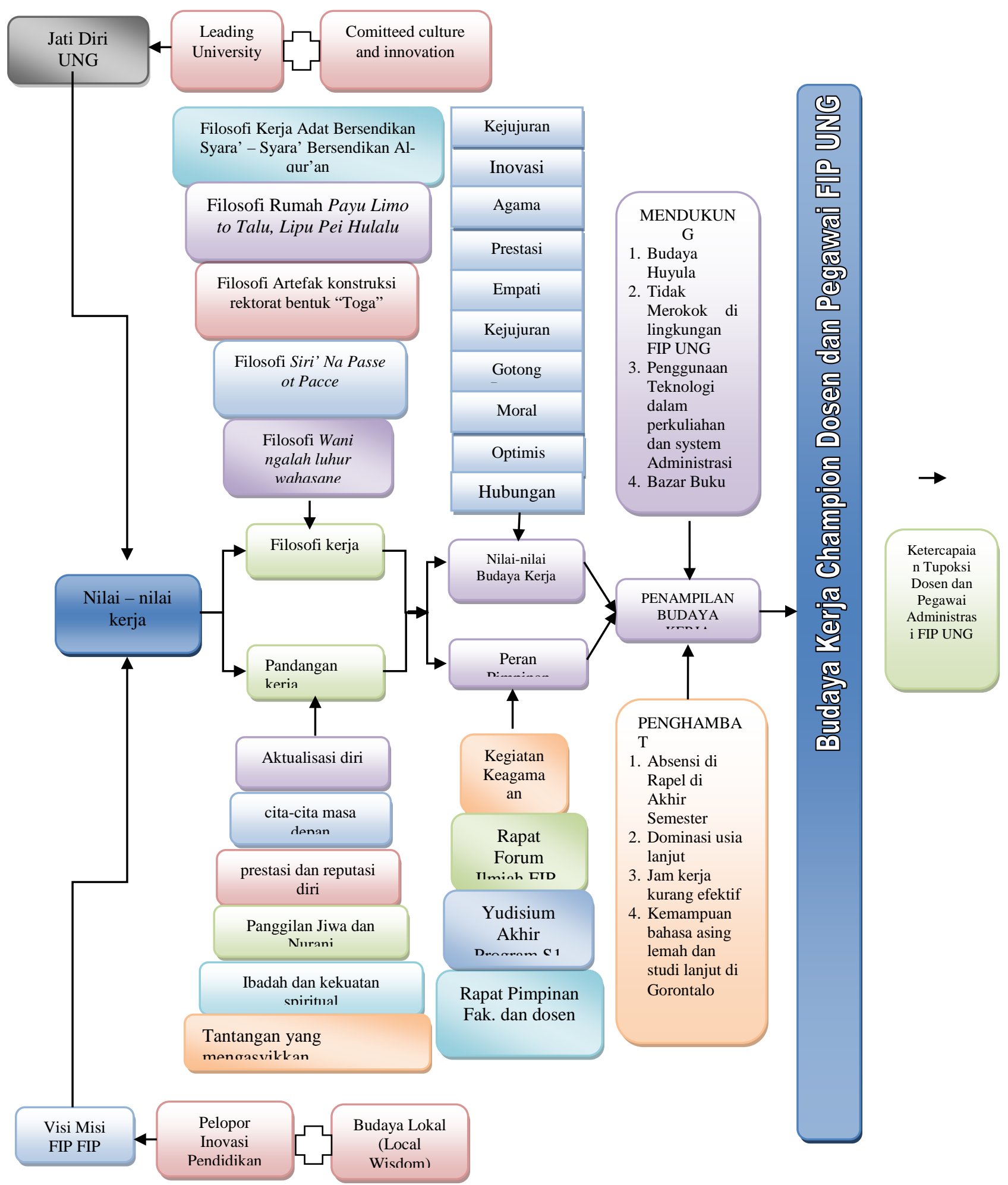

Gambar 1. Aspek Pendukung Budaya Kerja Champion Dosen dan Pegawai FIP UNG (Model diadaptasi dari Disertsi Arwildayanto, 2011) 


\section{HASIL DAN PEMBAHASAN}

Nilai-nilai Budaya Kerja Champion Dosen dan Pegawai, temuan penelitian ini mengidentifikasi nilai-nilai budaya kerja Champion terdiri dari Competitiveness Value, Honour Value, Achievement Orientation Value, Morality Value, Pioneering Value, Innovation Value, Optimism Value, and Nationalism Value yang diingin ditanamkan pada diri dosen dan pegawai FIP melalui pemahaman terhadap; a) visi dan misi FIP UNG, b) nilai-nilai kerja, c) filosofi kerja, d) pandangan kerja. Dalam pengembangan budaya kerja Champion dosen dan pegawai FIP UNG, direkonstruksi dengan baik aspek-aspek yang mendukung dan mengeliminir berbagai hambatannya yang dikenal juga dengan konsep budaya kerja yang berkualitas unggul di era kompetitif saat ini. Hal yang sama dijelaskan Norlina M. Ali et al. (2015; 163) bahwa In the face of intense competition, quality work culture can be seen on different levels. Researchers often discuss organizational or corporate culture in order to know deeper about the organization. They also stressed that to be effective, an organization must have clear and strong objectives, have high standards of excellence, have a work culture that supports employees, utilize teamwork, have technical training provided through on the job training, and have effective leadership. It is clearly stated that an effective organization must have a work culture that supports its employees. Clear objectives in term of mission and vision will lead the organization in a better way to success in future

Disamping itu, Kelompok sosial yang ada di FIP UNG juga turut mempengaruhi nilai kerja, salah satunya tempat dimana orang bekerja, misalnya dosen dan pegawai di FIP UNG memiliki ruang strategis menanamkan nilai-nilai kuat melalui pengalaman pribadi yang unik kepada pihak lainnya (Feather 1994;183-189). Disamping faktor kelembagaan yang mempengaruhi nilai-nilai kerja dosen dan administasi FIP UNG, menurut Arwildayanto (2012;199) kontributor lain adalah adanya kekuatan sosial, budaya, hubungan keluarga, dan keturunan yang turut mewarnai nilai kerja dosen dan pegawai bisa dilihat pada gambar 4.2 di bawah ini.

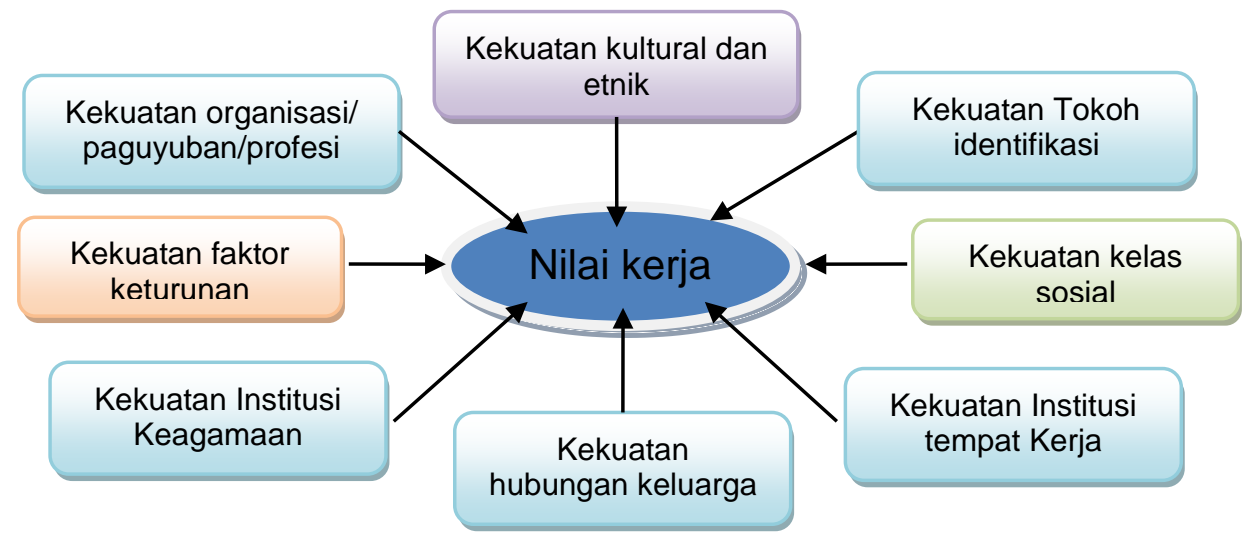

Gambar 2. Kekuatan-kekuatan yang Mewarnai Nilai Kerja (Arwildayanto 2012;58)

Disamping itu, dalam perspektif kultural dosen memahami nilai-nilai kerjanya tidak dapat lepas dari situasi unik instititusinya yang menjadi bagian sentiment dan keyakinan yang menyatu pada masing-masing dosen sebagai pribadi dalam interaksi kolegialnya (Sergiovanni and Cobally, 2010;16). 
Filosofi kerja dosen dan pegawai menjadi kontributor dalam pengembangan budaya kerja Champion bisa lihat dari simbol-simbol, artefak yang ada dalam melakukan interaksi di UNG, antara lain filosofi budaya Gorontalo yang disebut Payu Limo to Talu, Lipu Pei Hulalu, bangsa dijaga (bangusa talalo), negara dibela (lipu poduluwalo), diri diabdikan (batanga pomaya), harta direlakan (upango potombulu), nyawa dikorbankan (nyawa podungalo). Simbol-simbol budaya ini digunakan untuk menggerakkan orang-orang yang bekerja di kampus UNG. Schein dalam Ndraha (1999;44) yang membagi budaya dalam tiga tingkatan (level), terdiri dari, a) lowest level (tingkatan yang paling rendah) berisi kepercayaan yang dianut begitu saja (unconscious) berupa pemikiran dan perasaan dan lainnya yang menjadi nilai dan tindakan, dikenal juga dengan istilah basic underlying assumptions, b) espoused values, berisikan strategi, tujuan, dan filosofi kerja institusi, c), most visible level contain, tingkatan yang paling atas dan dapat diamati, diantaranya adalah struktur organisasi, situs, ritual, dekorasi, sistem reward dan penyelenggaraan manajemen pendidikan yang dikenal dengan sebutan artifak. Berikut ringkasan tingkatan budaya kerja institusi (lembaga) pendidikan tinggi (UNG) :

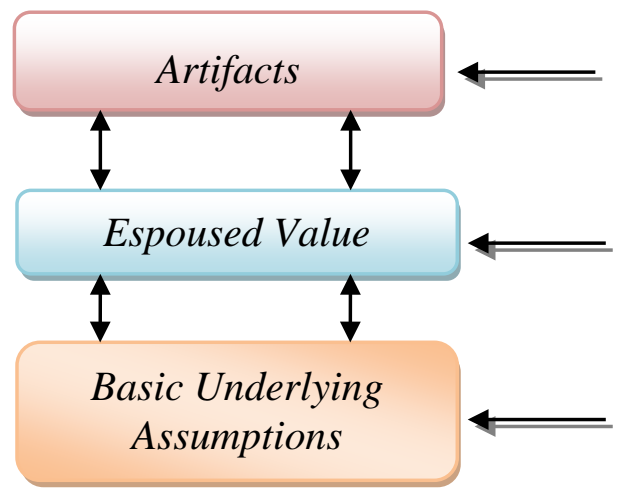

\section{Visible organizational structures and process (hard to decipher)}

\section{Strategies, goals, philosophies, (espoused justifications)}

Unconscious, taken-for-granted belief, perceptions, thoughts, and feeling (ultimate source of values and action)

Gambar 3. Tingkatan Budaya dan Institusi Kerja (Schein, 2004;27)

Filosofi lain yang mewarnai kerja dosen dan pegawai adalah filosofi Toga Wisuda yang terlihat dari artefak konstruksi bangunan rektorat UNG berbentuk toga. Makna filosofi ini agar cara berpikir (mind set) yang terbangun dari komunitas dosen dan pegawai melihat masalah dalam berbagai perspektif (kajian). Komunitas Gorontalo yang terkenal religious juga memiliki filosofi “Adat bersendikan syarak'-syara' bersendikan Al-qur'an (ABS-SBA) atau Adati Hula-hula'a to Sara'a, Sara'a Hula-hula'a to Kuru'ani memberikan andil besar dalam pembentukan budaya kerja Champion dosen dan pegawai FIP UNG.

Pemaknaan dari nilai dan filosofi kerja di atas memiliki multi fungsi nilai, 1) ditinjau dari kebutuhan personal dosen dan pegawai itu sendiri, 2) ditinjau dari kebutuhan institusi UNG tempat bekerja, dan 3) fungsi nilai ditinjau dari masyarakat Gorontalo tempat dosen beraktivitas dan beradanya kampus UNG. Misalnya filosofi ABS-SBA merupakan rumusan jati diri dan identitas kultural masyarakat Gorontalo, yang mayoritas memeluk agama Islam memiliki pesan moral agar warga Gorontalo senantiasa berpegang teguh kepada tali Allah SWT yang berlandaskan kepada nila-nilai keislaman. Termasuk dalam urusan tradisi kerja bisa digali dalam ajaran dan nilai-nilai agama Islam, jelas bahwa 
budaya kerja merupakan perintah Tuhan, melalui Surat Al-Jumuah (62:10), sebagai berikut :

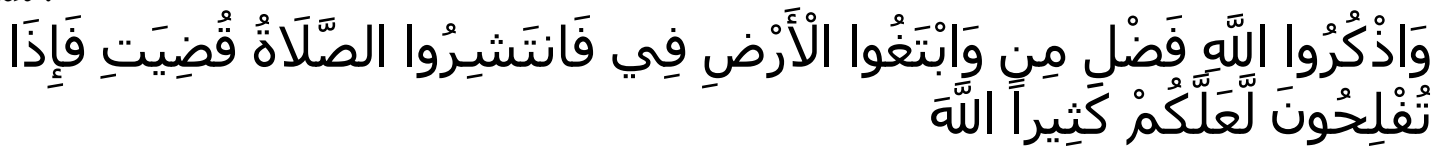

Artinya: Apabila telah ditunaikan Shalat, maka betebaranlah kamu dimuka bumi mencari karunia Allah, dan ingatkanlah Allah sebanyak banyaknya agar kamu beruntung

Hambatan Implementasi Budaya Kerja Champion, Ada beberapa penampilan kerja yang menjadi faktor penghambat, misalnya rapelan absensi perkuliahan di akhir semester. Penyebab perilaku kerja ini, ternyata bukan berasal dari nilai-nilai kerja yang dimiliki, melainkan dari faktor dukungan infrastruktur dan lingkungan kerja yang belum memadai, berupa jaringan Wifi belum memadai dan organisasi kerja belum kompetitif memberikan dampak produktivitas dan pencapaian Tupoksi kerja dosen dan pegawai belum sesuai harapan. Setelah diperbaiki dan perangkat infrastruktur dan dihadirkan beberapa dosen dan pegawai urban memberikan dampak yang signifikan terhadap perubahan penampilan kerja dosen dan pegawai. Dengan demikian peneliti menarik benang merahnya bahwa lingkungan kerja turut mempengaruhi pencapaian Tupoksi dosen dan pegawai FIP UNG. Senada dengan temuan ini, Potu, A. (2013; 1217) menjelaskan lingkungan kerja yang nyaman dan menyenangkan, akan membentuk budaya kerja yang cukup produktif sehingga setiap anggota selalu termotivasi untuk memberikan performa terbaiknya untuk menyelesaikan semua tugas-tugasnya sesuai dengan peran mereka. Disamping itu untuk membentuk organisasi kerja yang kompettitif, hambatan budaya kerja Champion dosen dan pegawai FIP UNG sebagai organisasi "hybrid" ini harus diminimalisirkan melibatkan mereka berpartisipasi dalam berbagai kegiatan secara teroganisir dan menumbuhkan kesadaran kerja itu adalah ibadah menuju pekerjaan yang professional dan berdaya saing tinggi. Hal ini sejalan dengan riset tentang tes komptetitif dari birokrasi organisasi oleh Dischner, S. (2015; 511) menyatakan "our study suggests that one strategy is to configure the organization as a hybrid that stimulates participation in decisions and formal standardization as well as avoids punishment systems.

Hambatan lainnya yang menarik dari implementasi budaya kerja Champion dosen dan pegawai FIP UNG adalah kebiasaan sebagian dosen dan pegawai pulang ke rumah dan tidur sejenak saat waktu istirahat. Mereka yang sudah terbiasa, kalau tidak tidur siang kepalanya jadi pusing. Temuan ini sejalan dengan fakta yang diungkapkan Ahmad Sobirin (2009;47) yang menceritakan pengalaman temannya ketika seorang dosen PTS dari Yogyakarta yang kebetulan ditugaskan menjadi dosen tamu di Gorontalo untuk beberapa lama, jauh-jauh hari diingatkan agar jangan kaget, jika pada siang hari Kota Gorontalo begitu sepi, karena tidur siang masih menjadi kebiasaan. Kebiasaan ini masih ada bagi dosen dan pegawai yang belum terbiasa hidup dan bekerja diluar Gorontalo. Trend beberapa 5 tahun terakhir ini menunjukkan semakin lama kebiasaan tidur siang ini semakin tergerus, seiring dengan banyaknya aktivitas dan tuntutan kerja dosen dan pegawai. Benchmarking, short course dan pendidikan lanjut yang diikuti dosen dan pegawai di luar Gorontalo memberikan kontribusi terjadinya perubahan pola kerja berorientasi memenangkan persaingan dengan entitas lainnya yang begitu gesit, akselaratif memanfaatkan waktu. Misalnya etnis China dan Makassar yang ada di Gorontalo, mereka menekuni sektor ekonomi didukung semangat kerja tinggi, dengan memperpendek waktu istirahat dan berhemat. Kesuksesan mereka didukung oleh Falsafah hidup yakni 
kesuksesan hanya milik mereka yang bertahan dan teruji dalam perjalanan waktu, akan terus bersinar sepanjang sejarah (Linda, L; 2010). Kahadiran kelompok urban tersebut memberikan dampak terjadi semangat kompetisi yang ingin dicapai dosen dan pegawai FIP UNG untuk mencapai aktualisasi diri yang menjadi mimpi besarnya masing-masing. Hal yang sama juga dijelaskan Cucu-Ciuhan, G., \& Guită-Alexandru, I. (2014;1) yang mengidentifikasi tipe budaya organisasi yang eksis di Univesitas Negeri Rumania dan melakukan evaluasi terhadap motivasi kerja terhadap 102 university teachers, aged between 25 and 57 disimpulkan bahwa "the the main o rganizational culture existent was the power type and that the employees hope for a support type. Teachers had a high selfactualization motivation"

Peran Pimpinan Fakultas dalam penerapan Budaya Kerja Champion. Peran pimpinan dalam penanaman budaya kerja Champion sudah berjalan dengan baik, regulasi dan pedoman pendukungan lainnya sudah tersedia. Hal ini dibuktikan dengan keputusan senat FIP UNG tanggal 25 Februari 2015 menyepakati budaya kerja Champion, dilanjutkan terbitnya surat keputusan Dekan tentang penetapan nilai-nilai budaya kerja, road map pengembangan budaya kerja dan pedoman pengukuran indeks pelaksanaan budaya kerja.

Berbagai regulasi dan kebijakan di atas menunjukkan peran pimpinan dalam bentuk implementasi komitmen berjalan dengan baik. Hal ini sejalan dengan hasil penelitian Rachmawati, E., Warella, Y. dan Hidayat, Z. (2006;95) yang menjelaskan bahwa peningkatan komitmen pimpinan dalam rangka meningkatkan budaya kerja dosen dan pegawai dengan cara pemberian contoh-contoh bekerja secara tepat waktu, pemberian teguran kepada dosen dan pegawai yang lalai akan tugasnya serta melakukan pengawasan yang lebih intensif terhadap pekerjaan yang dilakukannya. Peran pimpinan atau manajer yang baik dalam implementasi budaya kerja champion adalah yang mampu menciptakan suatu kondisi sehingga orang secara individu atau kelompok dapat bekerja dan mencapai kinerja yang tinggi.

Teknik-teknik penanaman budaya kerja dosen dan pegawai oleh pimpinan menurut Ndraha $(1999 ; 83)$ dilakukan melalui kegiatan didaktik-metodik pembinaan, pengarahan, pelatihan, dan brainwashing. Nilai-nilai yang dtanamkan pimpinan fakultas, berfungsi sebagai pendorong, pedoman dalam bekerja (Yvon Ambroise, 2000;20). Kemampuan pimpinan fakultas mempengaruhi dosen, mesti "getting things done through others, do right things atau do things right. Hal ini di dukung oleh proposisi "mestinya kita semakin rajin melaksanakan pekerjaan dengan mutu baik dan produktivitas tinggi dengan cara ini, kita mendapatkan nilai ibadah dan surga Allah SWT kelak”.

Untuk mengetahui peran lain dari pimpinan fakultas adalah kemampuan dekan dan wakil dekan FIP UNG dalam melakukan audit budaya yang masuk ke dalam organisasi yang dipimpinnya. Karena diketahui budaya dosen dan pegawai yang ada saat ini beranekaragam, ini menuntut inventarisasi sisi mana diperlukan penekanann, sebagaimana gambarkan di bawah ini.

Cara praktis, nilai-nilai budaya kerja Champion disosialisasikan pada segenap dosen dan pegawai administrasi FIP UNG dengan cara pimpinan fakultas mewujudkan hasil kerja dosen yang sesuai dengan visi, misi dan tujuan institusi/organisasi (Mulyadi dan Setyawan; 2000;12) 


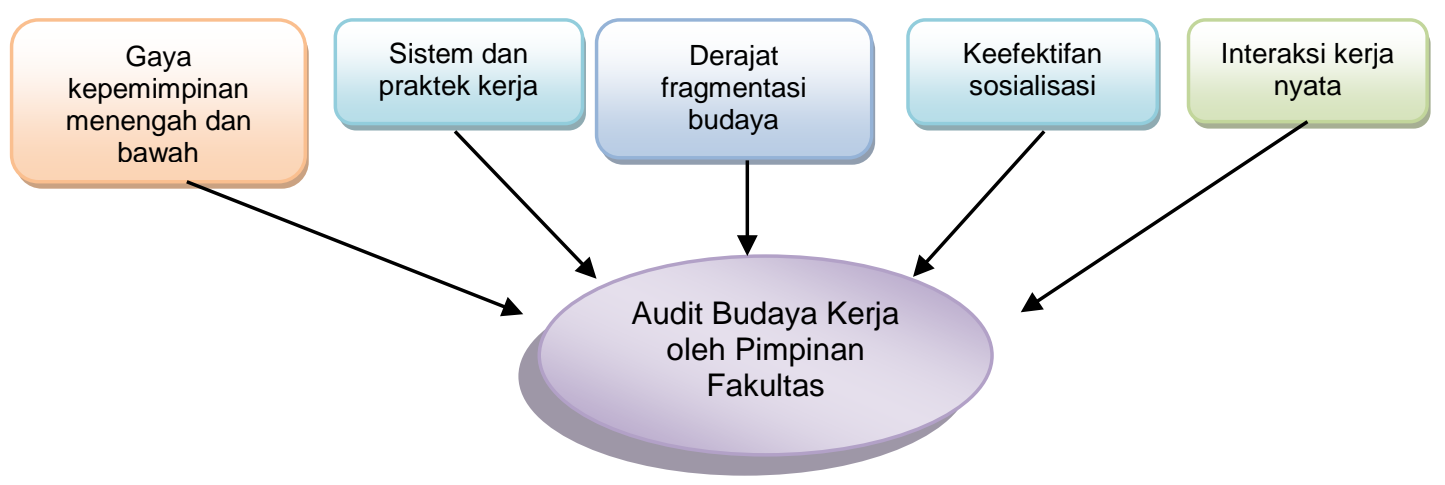

Gambar 4. Peran Pimpinan Fakultas dalam Pembinaan Budaya Kerja.

Akulturasi budaya kerja dosen dan pegawai dalam keanekaragaman dan kontak budaya. Dinamika kerja FIP UNG saat ini berlangsung dengan kondusif, proses akulturasi, berbasiskan nilai-nilai toleransi yang tinggi memberikan kontribusi terjadi hubungan kerja yang baik diantara dosen dan pegawai di lingkungan FIP UNG. Komunitas Gorontalo sebagai entitias kebudayaan yang terbuka dengan berbagai entitas budaya nasional lainnya. Hampir 40\% dosen dan pegawai FIP UNG berasal dari entitas di luar Komunitas Gorontalo. Secara alamiah Komunitas Gorontalo telah memberikan warna tersendiri dalam dinamika kerja dosen dan pegawai. Unsur-unsur budaya Gorontalo menjadi bagian dari nilai-nilai kerja dominan telah memungkinkan terjadinya kontak lintas budaya yang di bawah masing-masing dosen dan pegawai sesuai dengan budaya asalnya. Kondisi ini telah memberikan ruang yang sempurna bagi perubahan budaya yang lebih universal dalam keanekaragaman budaya, di dukung proposisi (P.14) ada 3 komunitas memberikan warna dalam pembentukan karakteristik budaya kerja di lingkungan FIP UNG, antara lain komunitas Gorontalo, komunitas Sulawesi Selatan yang berasal dari budaya Budaya Bugis dan Budaya Makasar dilanjutkan dengan komunitas Jawa dan sekitarnya. Budaya Hulondhalo yang mempengaruhi budaya kerja Champion dosen dan pegawai FIP UNG adalah budaya "Huyula” atau Gotong Royong, kebersamaan, didukung proposisi (P.15) daerah Gorontalo dirasakan daerah yang aman dan nyaman, tidak diskriminatif, penyayang (motoliango), kerjasama yang baik (mohuyula), sangat menghormati tamu. Burhanudin Domili (2015) menyatakan sistem gotong royong bukan saja pada kegiatan memenuhi kebutuhan hidup, misalnya membangun rumah, sarana ibadah, sarana pendidikan, membangun/membuat jalan, membuat fasilitas umum dan lainnya. Istilah Huyula juga mempunyai istilah lainnya, berupa: Ambu (tolong menolong antar kelompok untuk kepentingan bersama misalnya membuat jalan baru dan lainya), Hileiya (tolong menolong apabila ada kedukaan), Tiayo (tolong menolong antara kelompok orang untuk mengerjakan pekerjaan seseorang).

Komunitas Gorontalo yang religious juga menganut filosofi Adat Bersendi Syarak, Syarak Bersendikan Al-Qur'an, di dukung proposisi (P.15) nilai-nilai religious dalam kehidupan kami bisa dilhat dari proses budaya yang selalu berlandaskan Al-quran, misalnya pesta perkawinan, aqiqah anak, naik rumah baru, atau kantor baru dan prosesi budaya lainnya

Disamping itu etnis Bugis dan Makassar merupakan komunitas dominan kedua, turut memberikan warna dan dinamika dalam pengembangan budaya kerja dosen dan pegawai 
FIP dengan filosofi “siri' na pace” hal ini didukung proposisi (P.17) filosofi "Siri' $\mathrm{Na}$ Passe ot Pacce" merupakan karakter hidup yang diberikan leluhur kami untuk yang tinggal di kampung maupun dirantau ditanamkan nilai-nilai pekerja keras (gettang) dan lurus (lempuk), saling mengingatkan dalam kebaikan (malilu si pakainge), saling menolong dalam kesulitan (mali si parappe), saling member semangat dan motivasi (rabb si patokkang)

Pengaruh budaya kerja dosen urban lainnya yang turut mewarnai budaya kerja dosen dan pegawai berasasl dari etnis Jawa didukung proposisi (P.17) nilai-nilai "Wani ngalah luhur wahasane" atau mengalah untuk mencapai tujuan yang lebih mulia menjauhi dari konflik atau masalah. Makna nilai kerja yang diyakininya, kerja yang berorientasi pada nilai kaprawiran (kepahlawanan), dan kaprayitnan (kewaspadaan) nilai tulada (contoh nyata) dan nilai ngawat-awati (supervisi). Bahkan, tidak jarang mereka memberikan dorongan berkreasi (manun karso), mengunakan ungkapan nyuwun sewu (maaf) dan sumonggo (silahkan) dalam interaksi kerja maupun silaturahim dengan dosen lainnya (Arwildayanto, 2011).

Akulturasi kerja di atas sebagai fenomena tatkala kelompok-kelompok individu yang memiliki budaya berbeda terlibat dalam kontak secara langsung, disertai dengan perubahan terus-menerus, sejalan pola budaya asal dari masing-masing dosen. John W. Berry dkk, 1999;528). Akulturasi bisa terjadi dalam keanekaragaman budaya, struktural, komunitas, sikap bawaan, perilaku bawaan, tokoh identifikasi, perkawinan dan aspek lainnya, bisa digambarkan secara sederhana proses akulturasi budaya yang terjadi, sebagaimana Gambar 5 di bawah ini.

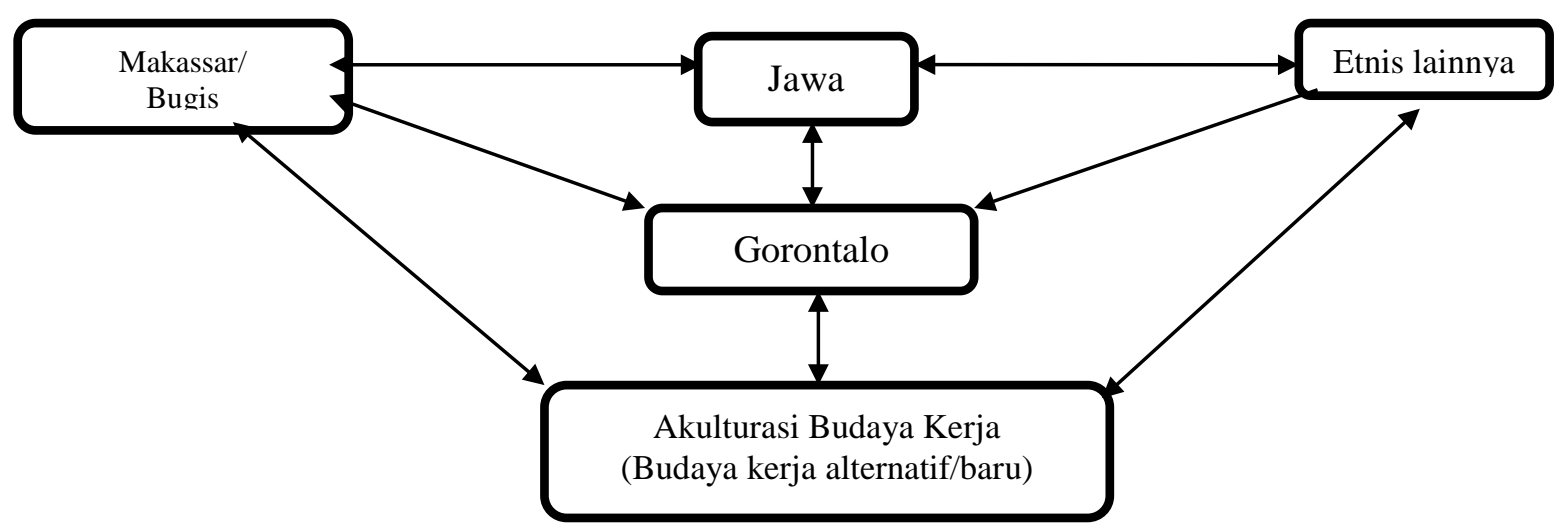

Gambar 5. Proses akulturasi budaya kerja dosen dan pegawai FIP UNG.

Pengelolaan akulturasi budaya kerja dosen dan pegawai dilakukan dalam rangka pengembangan fakultas dapat memberikan nilai tambah agar masing-masing dosen dan pegawai saling belajar memahami budaya koleganya (we understand from them, they understand from us). Akulturasi seperti ini adalah suatu pendekatan proaktif pada tingkatan praktis yaitu langsung dilakukan oleh orang-orang yang bekerja.

Ketercapaian Tupoksi Dosen dan Pegawai. Pelaksanaan Tupoksi dosen dan pegawai dan UNG dikategorikan sudah tercapai. Namun dari sisi kualitas layanan ketercapaian Tupoksi itu masih perlu ditingkatkan, karena belum menyentuh aspek kualitas layanan. Pelaksanaan budaya kerja champion dosen dan pegawai administrasi dengan pengukuran beban kerja dosen melalui sasaran kerja pegawai (SKP) dan pegawai administrasi belum 
memberikan pengaruh yang signifikan, karena besaran remunerasi dosen dan tunjangan kinerja pegawai masih bersifat "flate" merata tiap bulan, tidak akan yang menonjol atau turun drastis. Penentuannya besarannya masih dilihat dari jenjang jabatan structural atau kepangkatan yang dimilikinya. Padahal Sasaran Kerja Pegawai (SKP) yang ada dalam salah satu unsur di dalam Penilaian Prestasi Kerja PNS diatur dalam Peraturan Pemerintah Nomor 46 Tahun 2011. Penilaian Prestasi Kerja Pegawai Negeri Sipil dilaksanakan untuk mengevaluasi kinerja individu Pegawai Negeri Sipil, yang dapat memberi petunjuk bagi manajemen dalam rangka mengevaluasi kinerja unit dan kinerja organisasi. Amanat Pasal 12 dan Pasal 20 UU No. 43 Tahun 1999 mengamanatkan pembinaan PNS dilakukan berdasarkan sistem prestasi kerja dan sistem karier yang dititikberatkan pada sistem prestasi kerja dan untuk menjamin obyektivitas dalam mempertimbangkan pengangkatan dalam jabatan dan kenaikan pangkat diadakan penilaian prestasi kerja. Dalam realitasnya SKP yang diberlakukan tidak dengan serius dijadikan instrument untuk mengukur ketercapaian kinerja dosen dan pegawai. Karena setiap dosen dan pegawai yang memiliki jabatan struktural atau fungsional dijadikan ukurannya. Sehingga bagi yang tidak menjabat merasa tidak perlu lagi melakukan pekerja yang maksimal karena tetap mendapatkan remunerasi dan tunjangan kinerja yang sama tiap bulannya.

Pengaruh Budaya Kerja Champion Terhadap Ketercapaian Tupoksi Dosen dan Pegawai. Budaya kerja dosen dan pegawai administrasi di lingkungan FIP UNG, terdiri dari jati diri UNG, visi, misi FIP UNG, nilai kerja, pandangan kerja, indoktrinasi pimpinan dan penampilan kerja dalam konteks manajemen pendidikan tinggi sangat relevan untuk dipahami dan dikembangkan untuk mencapai sebuah mimpi besar menuju kampus yang bereputasi dan berprestasi pada tahun 2035 sesuai dengan visi UNG. Tanpa dukungan sumber daya manusia dosen dan pegawai administrasi mustahil cita-cita besar itu bisa diwujudkan.

Belum maksimalnya kinerja dosen dan pegawai terlihat dari beberapa penampilan kerja yang perlu sentuhan dengan membentuk tim task force yang berfungsi merubah cara berpikir, cara pandang, nilai-nilai kerja yang terbangun dengan baik, memperbaiki rutinitas pegawai, tata cara pelayanan, kebiasaan atau ritual kerja, dan non-fisik misalnya keyakinan, harapan, gagasan, atau impian pegawai. Karena budaya kerja itu diibaratkan seperti pupuk yang menyuburkan organisasi penyelenggara pelayanan untuk menghasilkan buah yang bermanfaat bagi publik.

Upaya melakukan perubahan pola pikir dan budaya kerja dosen dan pegawai FIP UNG yang ada sekarang (current culture), menjadi abdi Negara dengan integritas dan kinerja tinggi (desired culture) adalah sebuah pekerjaan besar dan membutuhkan komitmen serta kedisiplinan yang luar biasa, sumber daya yang besar dan waktu yang panjang. Oleh karena itu, agar perubahan budaya kerja dapat dilakukan dengan baik dan memberikan hasil yang diharapkan, perlu adanya pengelolaan yang baik. Pengelolaan terhadap perubahan biasa dikenal dengan istilah manajemen perubahan, seperti pada Gambar berikut.

Pada Gambar 6, untuk mendapatkan hasil terbaik, pertimbangan harus diberikan untuk mengelola budaya kerja dengan mengubah strategi memperhitungkan budaya kerja dalam manajemen perubahan. Mengelola perubahan budaya kerja dengan baik, perlu dikenali proses perubahan karakter budaya kerja, sebagai berikut: 1) Perubahan budaya kerja sebaiknya dilakukan secara evolusioner. 


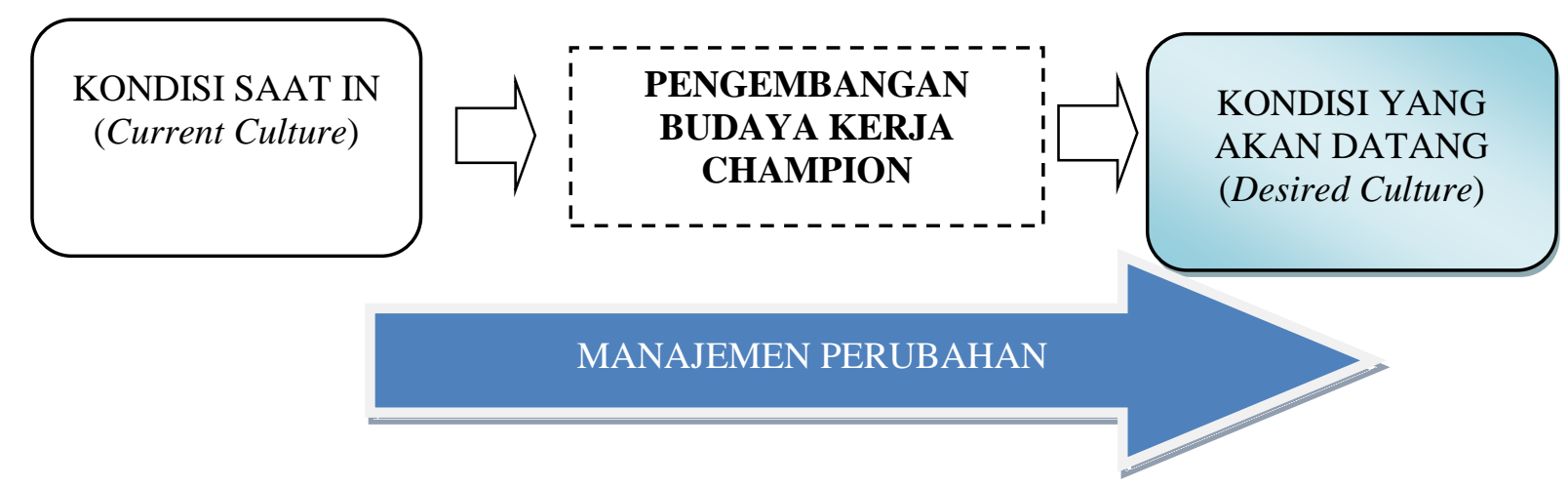

Gambar 6. Kerangka Manajemen Perubahan FIP UNG

(Sumber diadaptasi dari Permen PAN RB RI No. 39/2012 tentang Pedoman Pengembangan Budaya Kerja)

Karena kebanyakan orang yang mengalami perubahan budaya kerja akan berada pada kondisi psikologis yang dinamakan kejutan budaya (culture shock). Kejutan ini terjadi karena orang diminta bahkan terkadang dipaksa untuk keluar dari area nyaman (comfort zone), 2) perubahan budaya kerja merupakan aktivitas yang sangat kompleks. Satu kesalahan kecil dalam manajemen perubahan budaya kerja mengakibatkan kegagalan perubahan organisasi. Oleh sebab itu perubahan budaya kerja dilakukan secara terencana melalui sistem yang terstruktur dan komprehensif. 3) perubahan budaya kerja memerlukan proses yang berkelanjutan atau terus menerus. Seperti yang dilakukan FIP UNG dengan membuat regulasi yang jelas, road map pengembangan budaya kerja dan program kerja yang berorientasi penanaman nilai-nilai budaya kerja yang professional dan berpestasi.

Agenda yang perlu disiapkan FIP UNG untuk pengembangan budaya kerja Champion secara TSM merujuk pada agenda yang dilakukan Kemdiknas RI (2010,24-30, antara lain 1) penyediaan bahan sosialisasi perubahan budaya kerja, 2) intensifikasi sosialisasi perubahan budaya kerja, 3) Internalisasi perubahan budaya kerja Champion, 4) Pembentukan dan Penguatan Tim Pengembangan Budaya Kerja Champion, 5) Penguatan koordinasi para pemangku kepentingan, 6) Penegakan hukum bagi para pegawai, 7) Peningkatan kendali mutu pelayanan 8) Peningkatan sarana dan prasarana, 9) peningkatan moral dan akhlak seluruh dosen dan pegawai administrasi, 10) perwujudan organisasi belajar (learning organization)

\section{PENUTUP}

Kesimpulan, pertama Jari diri UNG, visi, misi FIP menjadi landasan yang kuat dalam pengembangan budaya kerja dosen dan pegawai administrasi FIP UNG, kedua Nilai-nilai kerja budaya kerja dosen dan pegawai administrasi yang dominan terdiri dari a) Kerjasama (Team Work), b) Inovasi (Innovation), c) Agama (Religious), d) Orientasi Berprestasi (Achievemen Orientation), e) Empati (Emphaty), f). Kejujuran (Fairness), g) Gotong Royong (huyula), h) Moral (Morality), i) Optimis (Optimism), j) Hubungan (Relationship), ketiga filosofi kerja yang terkonstruksi dari akulturasi filosofi kerja yang berasal dari entitas budaya asal masing-masing dosen dan pegawai administrasi. Keempat filosofi dominan yang mewarnai dinamika kerja FIP UNG, antara filosofi adat bersendikan syarak-syarak bersendikan Al-qur'an, filosofi “Siri' Na Passe ot Pacce” dan Wani ngalah 
luhur wahasane, kelima penampilan kerja yang muncul, antara lain gotong royong (huyula), tidak merokok di kampus, zakat buku, penggunaan teknologi dalam perkuliahan maupun urusan administrasi lainnya. Sedangkan penampilan kerja yang belum mendukungan perlu sentuhan dalam pengembangan budaya kerja oleh tim task force yang dibentuk FIP UNG. Ketercapaian pelaksanaan tugas oleh dosen dan pegawai administrasi masih bersifat subjektif, karena kualitas layanan dirasakan stakeholder masih perlu ditingkatkan.

Saran. perlu peningkatan sarana dan prasarana yang mendukung transformasi pengembangan budaya kerja, secara berkelanjutan dan kepemimpinan yang tidak boleh bosan dan berhenti dengan tantangan yang ada (nudge leaddership).

\section{DAFTAR RUJUKAN}

Ali, N. M., Jangga, R., Ismail, M., Kamal, S. N.-I. M., \& Ali, M. N. (2015) Influence of Leadership Styles in Creating Quality Work Culture. Procedia Economics and Finance, 31 (15): 161-169. http://doi.org/10.1016/S2212-5671(15)01143-0

Ambroise, Yvon. (1993) .Pendidikan Nilai Memasuki Tahun 2000, Jakarta: PT Gramedia Arianto, D. A. N. (2014) "Pengaruh Kedisiplinan, Lingkungan Kerja dan Budaya Kerja Terhadap Kinerja Tenaga Pengajar”. Jurnal Economia, 9(2): 191-200.

Arwildayanto, (2011) "Budaya Kerja Dosen (Studi Kualitatif di Universitas Negeri Padang)”, Disertasi, PPs Universitas Negeri Jakarta.

Arwildayanto, (2012) "Kepemimpinan "Nudge" dalam Pengembangan Budaya Kerja Dosen (Studi Kualitatif di Universitas Negeri Padang)”, Jurnal Manajemen , Volume XVI/01/Februari/2012; Jakarta: Universitas Tarumanagara.

Aycan, Z., Kanungo, R. N., \& Sinha, J. B. (1999) Organizational Culture and Human Resource Management Practices The Model of Culture Fit. Journal of Cross-Cultural Psychology, 30(4), 501-526. http://jcc.sagepub.com/content/30/4/501

Azaria, S; (2015) "Revitalisasi Peran Orang Tua Sebagai Kunci Keberhasilan Generasi dimuat dalam Proceeding Seminar Nasional "Selamatkan Generasi Bangsa dengan Membentuk Karakter Berbasis Kearifan Lokal”, publikasiilmiah.ums.ac.id

Berri, John W. dan kawan-kawan. (1999) Psikologi Lintas Budaya; Riset dan Aplikasi, Jakarta: PT Gramedia Pustaka Utama.

Bogdan, R., dan Biklen, S.K. (1998) Qualitative Research for Education and Instruction to Theory and Methods, Boston: Allyn and Bacon.

Burhanudin Domili, Budaya Gotong Royong (tolong-menolong) pada masyarakat suku bangsa Gorontalo, http://www.antaragorontalo.com/berita/288/budayawantutuhiya-bukan-budaya-negatif. Diakses pada tanggal 23 September 2015

Cucu-Ciuhan, G., \& Guită-Alexandru, I. (2014) "Organizational Culture Versus Work Motivation for the Academic Staff in a Public University”. Procedia - Social and Behavioral Sciences, 127: 448-453. http://doi.org/10.1016/j.sbspro.2014.03.288

Dischner, S. (2015) "Organizational structure, organizational form, and counterproductive work behavior: A competitive test of the bureaucratic and post-bureaucratic views". Scandinavian Journal of Management, 31(4): 501-514. http://doi.org/10.1016/j.scaman.2015.10.002

Faisal, Sanapiah (1990) Penelitian Kualitatit; dasar-dasar dan Aplikasi, Malang: Yayasan Asih Asah Asuh Malang. 
Feather, N. T. Dalam Lonner, Walter J.; Malpass, Roy S. (Ed.), (1994) Psychology and Culture, Massachusetts: Allyn \& Bacon.

Kementerian Pendidikan Nasional, (2010) Budaya Kerja Kementerian Pendidikan Nasional, Jakarta: Tim Reformasi Birokrasi Institusi (Tim RBI) Kemdiknas.

Keputusan Menteri Pendayagunaan Aparatur Negara No. 25/KEP/M.PAN/4/2004 tentang Pedoman Pengembangan Budaya Kerja Aparatur Negara.

Lembaga Administrasi Negara, (2004) Budaya Kerja Aparatur Pemerintah. Jakarta: Lembaga Administrasi Negara.

Lexi J. Moleong, (1998) Metodologi Penelitian Kualitatif, Bandung: Remaja Rosdakarya. Linda, L. (2010) Values dalam Diplomasi Ekonomi China. Jurnal Lingua Cultura, 4 (1).

Matthew B Miles and A. Michael Huberman, (1989) Qualitatif Data Analysis; A Sourcebook of New Methods, Newbury Park, California: SAGE Publication, Inc.

Moekijat. (1998) Asas-asas Perilaku Organisasi, Bandung : Alumni

Moleong, L.J. (2006) Metodologi Penelitian Kualitatif. Edisi Revisi. Bandung. PT Remaja Rosdakarya.

Mulyadi dan Setyawan J. (2000) Sistem Perencanaan dan Pengendalian Manajemen, Yogyakarta: Aditya Media.

Ndraha, Taliziduhu. (1999) Pengantar Teori Pengembangan Sumber Daya Manusia, Jakarta: Rineka Cipta.

Peraturan Pemerintah Nomor 46 Tahun 2011 tentang Penilaian Prestasi Kerja Pegawai Negeri Sipil

Peraturan Menteri Pendayagunaan Aparatur Negara dan Reformasi Birokrasi Republik Indonesia Nomor 39 Tahun 2012 tentang Pedoman Pengembangan Budaya Kerja.

Potu, A. (2013) “Kepemimpinan, Motivasi, dan Lingkungan kerja pengaruhnya terhadap kinerja karyawan pada Kanwil Ditjen Kekayaan Negara Suluttenggo dan Maluku Utara di Manado”. Jurnal Riset Ekonomi, Manajemen, Bisnis dan Akuntansi, 1(4).

Rachmawati, E., Warella, Y., \& Hidayat, Z. (2006) "Pengaruh Motivasi Kerja, Kemampuan Kerja Dan Gaya Kepemimpinan Terhadap Kinerja Karyawan Pada Badan Kesatuan Bangsa Dan Perlindungan Masyarakat Propinsi Jawa Tengah”. Jurnal Ilmu Administrasi dan Kebijakan Publik, 3 (1), 89-97.

Robbins, SP. (1996) Perilaku Organisai; Konsep Kontroversi, Aplikasi, ED Indonesia. Jakarta:.PT. Prenhallindo.

Schein, Edgar H. (2004) Organizational Culture and Leadership, San Fransisco: JosseyBass

Sergiovanni, T.J., and J.E. Corbally. (2002) Leadership and Organizational Culture, Urbana: University of Illionis Press.

Sobiri, Ahmad Sobirin, (2009) Budaya Organisasi, Pengertian dan Aplikasinya dalam Kehidupan Organisasi Edisi Kedua Yogyakarta: UPP STIM YKPN.

Sugiyono. (2011) Metode Penelitian Kombinasi, Bandung. CV. Alfabet.

Sun, S. (2008) “Organizational Culture and Its Themes”. International Journal of Business and Management”, 3 (12): 137. Retrieved from http://www.ccsenet.org/journal/index. php/ijbm/article/view/760

Supriyadi dan Triguno. (2006) Budaya Kerja Organisasi Pemerintah - Bahan Ajar Diklat Prajabatan Golongan I dan II. Jakarta: LAN.

Tintami, L, Pradhanawati, A., \& Nugraha, H. S. (2013) "Pengaruh Budaya Organisasi dan Gaya Kepemimpinan Transformasional terhadap Kinerja Karyawan melalui Disiplin 
Kerja pada Karyawan Harian SKT Megawon II PT”. Djarum Kudus. Jurnal Ilmu Administrasi Bisnis, 1(1): 189-196.

Undang-undang Nomor 14 tahun 2005 tentang Guru dan Dosen

West, MA. (2000) Mengembangkan Kreativitas dalam Organisasi. Ed.1 Yogyakarta. Kanisius.

Widodo, T. (2012) "Pengaruh Lingkungan Kerja, Budaya Organisasi, Kepemimpinan terhadap Kinerja (Studi pada Pegawai Kecamatan Sidorejo Kota Salatiga)”. Jurnal Ilmiah Among Makarti, 3 (5).

William G. Tierney (1988) "Organizational Culture in Higher Education: Defining the Essentials”, The Journal of Higher Education, 59 (1) (Jan. - Feb., 1988): 2-21. Publikasi http://www.jstor.org/stable/1981868 